\title{
A Proposal for Mapping Historic Irrigation Channels to Reveal Insights into Agro-Climatic Systems: A Case Study in Upper Austria
}

\author{
Christian NEUWIRTH ${ }^{1}$, Sebastian D'OLEIRE-OLTMANNS ${ }^{2}$ and Clemens EISANK ${ }^{2}$ \\ ${ }^{1}$ DK GIScience, Salzburg/Austria · christian.neuwith@stud.sbg.ac.at \\ ${ }^{2}$ Z_GIS, Salzburg/Austria
}

This contribution was double-blind reviewed as full paper.

\begin{abstract}
Recently, the remains of two historic irrigation channels were re-discovered in the Upper Austrian municipality of Regau. Since the current average precipitation in the region is sufficient to sustain a productive agricultural land use, the irrigation channels raise several questions related to climate variability. To verify different hypotheses such as the construction as a response to a changing climate or the assumed purpose of grassland irrigation, potential coherences are discussed. In addition, remote sensing techniques for the detection of hidden structures overprinted by physical and human activities are outlined.

The analysis of available references enables a first assessment of the channels purpose. Several indicators such as the shape and incline of the remaining topographic imprints support the hypothesis of their irrigation function. Furthermore, the qualitative analysis of today's agro-climatic conditions reveals the general vulnerability of the system to climate changes. Moreover, a dendrochronological analysis shows a phase of remarkable climate variability in conjunction with significant drying periods throughout the $3^{\text {rd }}$ and $4^{\text {th }}$ century. This may have posed a reason for the construction of the irrigation system.

Further research is necessary to verify the possible alternative hypothesis, which suggests grassland fertilization as the main irrigation purpose. Therefore, a long term analysis of water nutrient contents is required. Moreover, the application of remote sensing techniques may help to identify the extent of the formerly irrigated area.
\end{abstract}

\section{Introduction}

Environmental changes have a significant impact on the agricultural system. Therefore, agriculture may be considered as an open system which is affected by outside disturbances such as climate changes. To cope with these changes, land owners have to apply adaptation strategies. One strategy of climate adaptation is the implementation of artificial irrigation techniques to overcome hydro-climatic limitations in dry regions. According to ALLEN et al. (1998) the amount of irrigation water required for irrigation is the difference between the amount of water needed by the crop and the effective precipitation. Thereby, factors such as 
topography, soil or the prevailing climatic conditions determine the water that is available for a specific crop. Whereas topography and soil are relatively static factors over time, climate may change in the medium term.

In this contribution the example of an historic irrigation system in Upper Austria is utilized to propose a case study for climate change driven impacts on agricultural structures. Thereby, the major aim is to learn from the past to assess the potential effects of climate change in the future. A complete mapping of the channels topographic imprints may help to evaluate the extent of the irrigated area based on terrain analysis. For mapping, different methods focused on remote sensing, will be discussed. This proposal is considered as a call for interdisciplinary research on climate and history. It may also reveal new insights that are important for climate change impact assessment and mitigation.

\section{Agriculture and Irrigation in Regau}

BERLINGER (1926) described the remains of two historic irrigation channels reaching from the so called Ager river to an extensive fluvial terrace located in the municipality of Regau (Upper Austria) (see Fig. 1). According to the discoverer of the irrigation system, the main purpose of these channels was to ensure the irrigation of grassland, and thus sufficient production of grass and hay, which travellers along the Roman road needed for feeding their horses. The road connected the Roman settlements Iuvavum (Salzburg) and Ovilava (Wels) (FISCHER 2002). Therefore, it is assumed that the irrigation network dates back to the times of the Roman occupation between the $1^{\text {st }}$ and $5^{\text {th }}$ century. However, even though HASSLER (1995) also mentioned Romans as inventors of grassland irrigation techniques, no distinct evidence for a Roman origin was yet found in Regau.

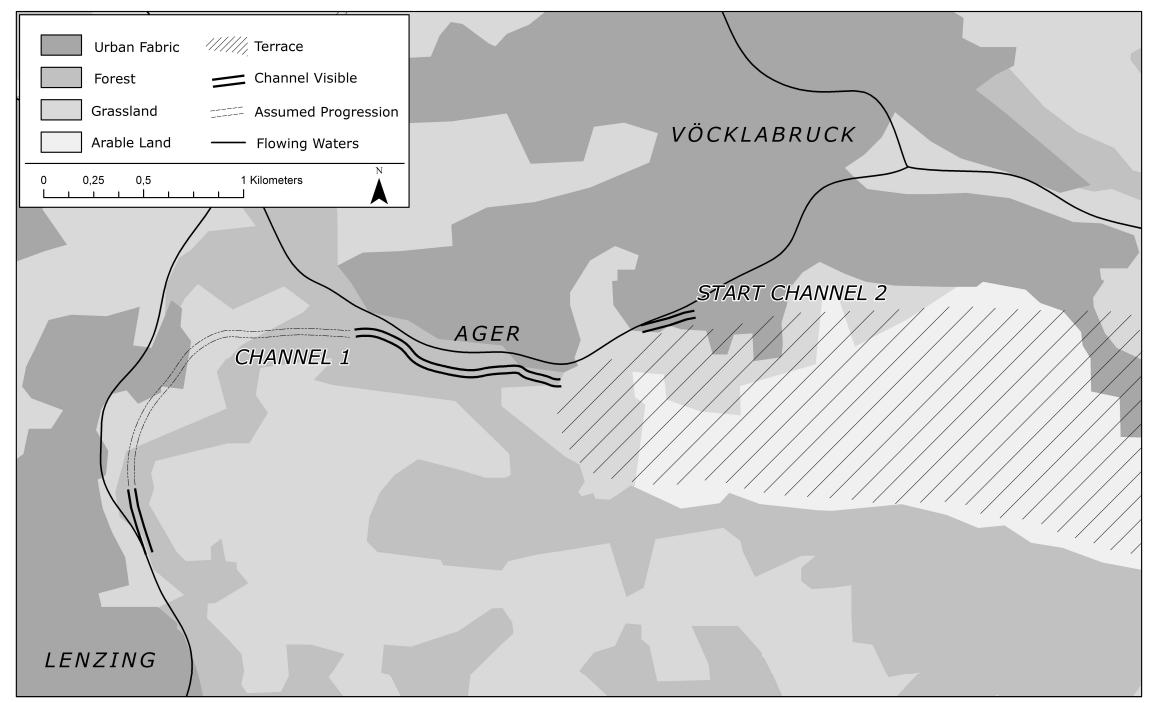

Fig. 1: Map of the study area and the irrigation channels. The land cover patches were adapted from Corine Land Cover (2006) 
However, there are several indications that support the hypothesis of their irrigation function. Firstly, both channels show a continuous descent, starting from the Ager river and facing towards the agricultural plain. Thereby, the origin of channel 1 at the river bank exhibits just a slightly higher altitude than the assumed outlet (about $8 \mathrm{~m}$ height difference). This minimizes the required channel length as well as the efforts for the construction. Moreover, minor descents guarantee low erosion rates as well as the desired slow flow velocities at the outlets. Accordingly, the courses of the channels were thoroughly designed to redirect river water to the terrace.

Besides, the irrigation of grassland seems to be quite reasonable, since water supply is a major limiting factor of productive grassland agriculture (BOHNER 2003). BUCHGRABER \& GINDL (2004) mentioned a minimum precipitation requirement of about $800 \mathrm{~mm}$ per year. For the Regau region a yearly precipitation average of $1050 \mathrm{~mm}$ (weather station Vöcklabruck; LEBENSMINISTERIUM 2012) was recorded for the period 1971 to 2009. Thus, the suggested precipitation limit was exceeded by $250 \mathrm{~mm}$. However, permeable and shallow soils (cf. BFW 2007) as well as massive fluvial gravel accumulations lead to relatively dry conditions. The precipitation surplus is needed to maintain profitable grassland agriculture.

To obtain more information on the actual hydrological situation as well as natural limitations of agricultural land use, two land owners were interviewed. Both emphasized that the annual water supply is sufficient for crops such as rape, cereals, potatoes, soy, sunflowers, pumpkins as well as grassland. At the moment, the land owners do not see any need for artificial irrigation. However possible changes towards a drier climate are considered as a major threat to agricultural productivity in the region, since soils are not able to compensate for longer dry periods.

Although climate warming recently led to a transition from grassland land use and animal farming to arable farming, about a tenth of today's land use is still grassland without any irrigation. It seems that, the transition from grassland to arable land use is not necessarily a consequence of environmental limitations, but of new opportunities due to the milder climate. Current hydro-climatic conditions allow both, grassland and arable agriculture.

This brings up the question: Why did the constructors of the irrigation system take the high effort of building the channels to irrigate the terrace in the past? BERLINGER (1926) proposed the lack of fertilizer as a possible reason.

\section{Impact of Irrigation}

Water transports dissolved nutrients that are needed by the plant (SCHAUMBERGER 2011). Consequently, irrigation fosters the nutrient transport to the plant, but can also lead to the leaching of soil nutrients. The nutrient content of the irrigation water is an essential factor which determines the effect of irrigation on grassland yields. According to KLAPP (1971) grassland irrigation water requires a balanced proportion between nutrients such as phosphorus, nitrogen and potassium to improve plant growth. Furthermore, the irrigation water should be relatively alkaline to prevent the soils from acidification. Acidic soils lead to reduced nutrient uptake and therefore hinder plant growth. For instance, experiences from South Germany (Schwarzwald) show a negligible improvement of grassland yields (67\%) due to acidic and relatively nutrient-poor irrigation waters (HASSLER 1995). 
Measurements of $\mathrm{pH}$-values nearby the assumed origin of the irrigation channel 1 (see Fig. 1) show alkaline values of about 8 . Reference measurements at the upper course of the river even show slightly higher values. Thus, the $\mathrm{pH}$-values seem to be suitable for grassland irrigation. However, phosphorus and nitrate in the lower course (about $30 \mathrm{~km}$ from the assumed origin of the irrigation channel) exhibit relatively low concentrations of $0,05 \mathrm{mg} / \mathrm{l}$ and $0,012 \mathrm{mg} / \mathrm{l}$, respectively (PHILIPPITSCH \& GRATH 2011). These values are probably even lower upstream, since the Ager originates from the Attersee, which is considered as very nutrient poor and oligotrophic lake (AIGNER 2011).

Even though water conditions may differ from the past, current nutrient concentrations are probably even higher due to fertilizer input from adjacent agricultural areas. The same applies to $\mathrm{pH}$-values which may have increased due to the lime treatment of soils within the catchment. Based on these considerations, the irrigation had probably no fundamental fertilizing effect on the crops.

Therefore, the bridging of dry summers and the adaptation to the prevailing climate conditions were probably the main motivations for constructing irrigation channels. For instance, maintenance of sufficient growth rates during the summer was the main purpose for grassland irrigation in the relatively dry German region Kraichgau until the dawn of modern agriculture (HASSLER 1995). In the $20^{\text {th }}$ century fertilizers gained increasing importance as a means to overcome dry periods. However, since organic farming in conjunction with efforts to reduce fertilizer has a strong tradition in the study area, a closer look at historic climate variations and possible impacts is required.

\section{Climate History of Central Europe}

The evaluation of interrelationships between climate variations and their historic consequences is currently subject of intensive research among historians, climatologists and archaeologists. Historic climate chronologies can be reconstructed using proxies such as tree rings, ice cores, speleothems or pollen deposits (MCCORMICK et al. 2012).

For instance, BÜNTGEN et al. (2011) used 7284 relict oaks from Lorraine, North and South Germany to assess precipitation variability in Central Europe. Oak trees are sensitive to the precipitation amount between April and June (AMJ). Therefore, the tree ring width serves as a proxy for the precipitation variability. Furthermore, tree ring width of stone pines turned out to be suitable for the assessment of summer temperatures (JJA). In the study 1089 relict trees from the Austrian Alps were considered. Both proxies allowed for the reconstruction of a precipitation and temperature chronology, which covers 2500 years of Central European climate history (see Fig. 2). 


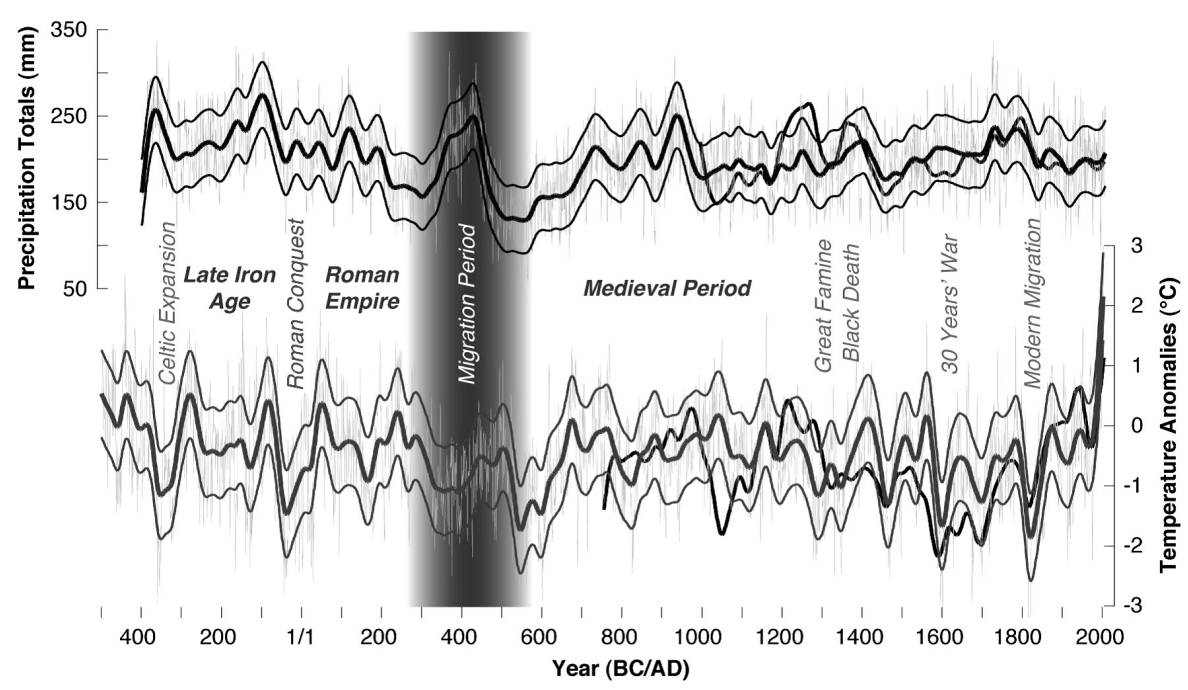

Fig. 2: Reconstructed AMJ precipitation totals (top) and JJA temperature anomalies (bottom). Error bars represent \pm 1 RMSE of the calibration period. Bold lines were derived by the application of a 60-year low-pass filter. Historic milestones are marked (BÜNTGEN et al. 2011).

The resulting curves indicate a distinct drying in the $3^{\text {rd }}$ century, accompanied by still relatively warm conditions. Precipitation increases in the $300 \mathrm{~s}$, before it sharply drops again in the first half of the $6^{\text {th }}$ century. The climate variability after a long phase of relatively stable and wet conditions during the expansion of the Roman Empire (cf. MCCORMICK et al. 2012) was maybe one trigger that led to the construction of the irrigation system in Regau.

\section{$5 \quad$ Remote Sensing Techniques}

For the mapping of the irrigation system, remote sensing (RS) technologies are foreseen. One aim is to acquire a high resolution digital elevation model (DEM) for a comprehensive topographic analysis. For example, DEM-derived parameters such as slope azimuth and slope gradient may support the estimation of the irrigated area extent. In addition, it is an open issue if - apart from the partly traceable main irrigation channels - additional irrigation channels were constructed in the Regau region.

Since field-based surveys are time- and labor-intensive, RS is considered the main source for mapping the structure of the irrigation system. Many parts of the historic system have been overprinted by either physical processes (e.g. erosion, accumulation) or human activities (e.g. levelling); other parts are covered by dense vegetation. RS techniques such as LiDAR (Light Detection and Ranging) penetrate vegetation structures and sample ground surface elevations in high detail (NELSON et al. 2009). Based on the resulting point clouds, accurate DEMs are produced that may reveal the topographic imprint of historic channels. 
In addition aerial photographs, taken by means of an unmanned aerial vehicle (UAV) will be used. UAV-based remote sensing has been proven to be a valuable methodology for mapping purposes. Recently, a mapping approach for soil erosion was published (D'OlEIRE-OltMANNS et al. 2012). This approach allows for an accurate mapping of the current environmental conditions. Applying this approach to the Regau region may add further value for mapping the imprints of historic channels. The acquired aerial photographs contain a very high spatial resolution. Hence, identified imprints in the LiDAR DEMs will be linked with optical information from the current surface derived from the aerial photographs. Fig. 3 illustrates a DEM derived from aerial photographs.

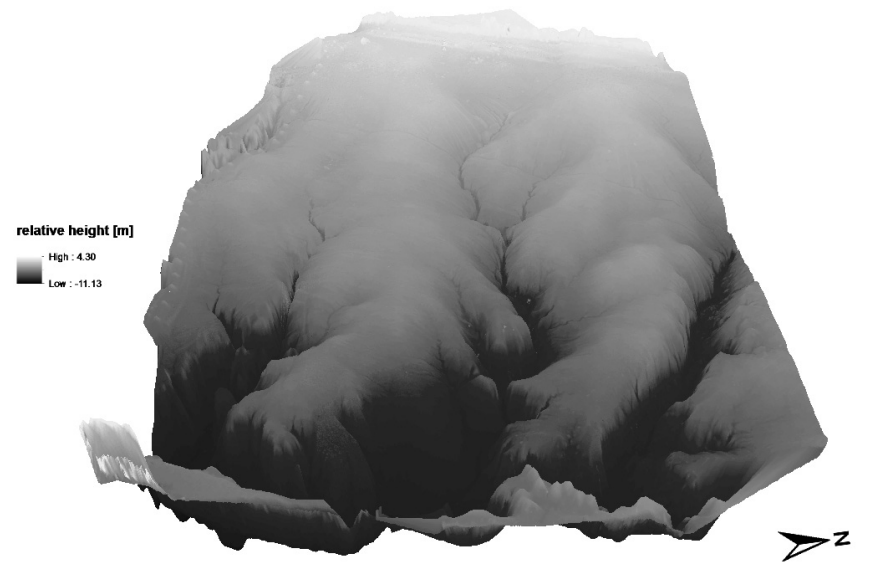

Fig. 3: Example of a digital elevation model derived from aerial photographs

These imprints appearing in the DEMs and in UAV-based aerial photographs may be mapped either through manual visual interpretation or through (semi-)automated methods such as object-based image analysis (OBIA) (BLASCHKE 2010). Both manual and (semi-) automated mapping can be supported by land-surface parameters (LSPs) and land-surface objects (LSOs) that are computed from DEMs. Basic LSPs such as curvature or slope are continuous models describing local morphological properties of the land surface, whereas LSOs structure the land surface into discrete spatial units such as landforms or watersheds (PIKE et al. 2009).

OBIA seems to be a valuable approach for (semi-)automated detection of channel structures in high resolution RS data. Recently, OBIA was successfully employed in a study on predictive archaeological mapping based on RS data (VERHAGEN \& DRAGUT 2012). OBIA applies image segmentation to merge image pixels to segments, thus reducing unnecessary detail. If a DEM or LSP serves as input layer for the segmentation, resulting segments are a sort of LSOs, though rather basic. Through the application of contextual and morphological rules the segments are aggregated to units that may represent the channels or part of the channels. Gaps in the network can easily be closed by applying additional context rules. 


\section{Conclusions and Outlook}

The content of the paper is rather hypothetical and is especially intended to encourage further discussions on climate change and agriculture. Although there is no clear evidence for a Roman origin of the irrigation channels or an exclusive grassland land use, the presented example illustrates a possible climate change impact on agricultural structures.

A change towards a drier climate may require grassland or crop irrigation even in a currently very wet region. Thereby, gravel terraces such as those in Regau are more susceptible since the high permeability of the subsurface leads to a distinct vulnerability to hydroclimatic variations. Thus, the study area constitutes a relatively unstable agricultural system (cf. FORD 2010). Even small changes of climate can, under certain conditions, have sustainable effects on agrarian economy.

On the contrary, different techniques of modern agriculture such as the use of artificial fertilizers or cropping optimization methods may facilitate the adaptation to environmental changes. Moreover, knowledge on distinct problems and challenges in the past is required to select appropriate mitigation measures in the future. The presented case study constitutes a suitable example to further elaborate on this issue.

One major focus of our further research is to fully ascertain the extent to which irrigation of the terrace was required in the past. Thereby, field mapping of the channels will greatly benefit from the integration of RS data. In contrast to field investigations, where the observer is part of the system, RS techniques place the observer above the system. Therefore, RS data enables the perception and analysis of the phenomenon of interest at a broader scale. This scale differs from the local field perspective, which is restricted to the immediate surroundings. For instance, RS data may provide additional context that is required especially for mapping overprinted channel parts that are not recognized in the field.

Moreover, a long term analysis of water nutrient contents is required in order to find out about the fertilizing effect of irrigation waters. The inflow of nitrogen and phosphorus from intensively cultivated agricultural surfaces may lead to significant seasonal variations and to a bias of natural nutrient contents in the river. Information on natural nutrient contents is especially important for the assessment of the irrigation purpose. This is also an essential working step to evaluate the hypothesis of irrigation in response to a changing climate.

\section{Acknowledgements}

This research is funded by the Austrian Science Fund (FWF) through the Doctoral College GIScience (DK W 1237-N23).

\section{References}

Aigner, G. (2011), Badegewässerprofil - Attersee. Badegewässerprofile. Wien, Bundesministerium für Gesundheit. 
Allen, R. G., Pereira, L. S., Raes, D. \& Smith, M. (1998), FAO Irrigation and drainage. Rome.

BERLINGER, J. (1926), Über Bodendenkmale. Heimatgaue, Zeitschrift für Oberösterreichische Geschichte, 7, 194-201.

BFW (2007), ebod [Online]. http://gis.lebensministerium.at/eBOD/frames/index.php?\&gui_id=eBOD (24.01.2013).

BLASCHKE, T. (2010), Object based image analysis for remote sensing. ISPRS Journal of Photogrammetry and Remote Sensing, 65 (1), 2-16.

BoHNER, A. (2003), Floristische Diversität im Spannungsfeld zwischen Landwirtschaft und Naturschutz - Ein aktueller Situationsbericht mit Blick in die Zukunft. Alpenländisches Expertenforum zum Thema "Das österreichische Berggrünland". Gumpenstein, Irdning, Austria, Bundesanstalt für alpenländische Landwirtschaft [BAL], 29-39.

BuCHGRABER, K. \& GINDL, G. (2004), Zeitgemässe Grünlandbewirtschaftung. Graz, SLV.

Büntgen, U., Tegel, W., Nicolussi, K., McCormick, M., Frank, D., Trouet, V., KaPLAN, J. O., HERZIG, F., HEUSSNER, K. U. \& WANNER, H. (2011), 2500 years of European climate variability and human susceptibility. Science, 331, 578-582.

D'Oleire-Oltmanns, S., Marzolff, I., Peter, K. D., Ries, J. B. (2012) Unmanned Aerial Vehicle (UAV) for Monitoring Soil Erosion in Morocco. Remote Sensing, 4 (11), 33903416.

FISCHER, T. (2002), Noricum: Orbis Provinciarum. Mainz, PHVZ.

FORD, A. (2010), Modeling the environment. Washington, Island Press.

HASSLER, M. (1995), Der Einfluß der Wässerung Wässerwiesen: Geschichte, Technik und Ökologie der bewässerten Wiesen, Bäche und Gräben in Kraichgau, Hardt und Bruhrain. Ubstadt-Weiher, LNV.

Klapp, E. (1971), Wiesen und Weiden - Eine Grünlandlehre. Berlin/Hamburg, Parey.

LEBENSMINISTERIUM. (2012), ehyd [Online]. http://ehyd.gv.at/ (24.01.2013).

McCormick, M., Büntgen, U., Cane, M. A., CoOK, E. R., Harper, K., Huybers, P., Litt, T., Manning, S. W., Mayewski, P. A., More, A. F. M., Nicolussi, K. \& Tegel, W. (2012), Climate change during and after the Roman empire: Reconstructing the past from scientific and historical evidence. The Journal of Interdisciplinary History, 43, 169-220.

Nelson, A., Reuter, H. I. \& Gessler, P. (2009), DEM Production Methods and Sources. In: Hengl, T. \& Reuter, H. I. (Eds.), Geomorphometry-Concepts, Software, Applications. Developments in Soil Science, 33, 65-85. Amsterdam, Elsevier.

PHILIPPITSCH, R. \& GRATH, J. (2011), Wassergüte in Österreich, Jahresbericht 2011. Umwelt und Wasserwirtschaft. Bundesministerium für Land-und Forstwirtschaft.

Pike, R. J., Evans, I. S. \& Hengl, T. (2009), Geomorphometry: A Brief Guide. In: Hengl, T. \& Reuter, H. I. (Eds.), Geomorphometry - Concepts, Software, Applications. Amsterdam, Elsevier, 3-30.

Schaumberger, A. (2011), Räumliche Modelle zur Vegetations- und Ertragsdynamik im Wirtschaftsgrünland. Dissertation, Technische Universität Graz.

VERHAGEN, P. \& DRĂGUT, L. (2012), Object-based landform delineation and classification from DEMs for archaeological predictive mapping. Journal of Archaeological Science, $39(3), 698-703$. 